\title{
The supply risk analysis process in small and medium-sized enterprises
}

\section{Introduction}

Risk analysis plays an increasingly important role in the operation of enterprises, financial institutions and commercial organizations, whose agenda is not only the intention to stay in the market, but also to generate profits. In many cases, they lack appropriate methodology and the entire procedure is carried out in an intuitive and informal manner.

The aim of this paper is to present the supply risk analysis process in the example of enterprise $\mathrm{X}$, as well as to present possibilities for its adoption by small and medium enterprises.

\section{Supply risk in the SME sector}

Supply risk is all the risk connected with conditions of purchasing commodities and services (table 1).

M.Sc. Maciej Kozaryn University of Zielona Góra Faculty of Mathematics, Computer

Sciences and Econometry

M.Sc. Eng. Wiesław Wasilewski

University of Zielona Góra

Faculty of Economics and Management
The notion of supply risk can be therefore understood as the possibility of nonachieving an objective, connected with assumed quality, quantity, deadline, and the price of the delivery.

The methods that can be implemented in the field of supply are: the policy of commodities, 
the contraction policy, the communication policy and the purchasing policy. It should be noted that one of the most popular solutions to dealing with the risk of supply in production-oriented enterprises is creation and supplementation of stocks (this is part of the policy of commodities).

Table 1. Types of risk in supply

\begin{tabular}{l|l}
\hline Type of risk & Description \\
\hline Qualitative risk & The ordered commodity does not meet quality criteria \\
\hline Temporal risk & The deadline of delivery has been missed. \\
\hline Price risk & Increase of prices of commodities \\
\hline Quantitative risk & The ordered quantity of commodities has not been delivered. \\
\hline
\end{tabular}

Source: Own work on the basis of Zellmer 2010, p. 22

It is widely assumed that the aim of these stocks is to limit the risk connected with differentiation between supply and demand, having its roots in the micro (and macro) scale surroundings of the enterprise.

Uncertain conditions in the supply field are determined by (Tempelmeier 2000, p. 257):

1. The level of demand for a given resource, which can vary during the entire period of a plan's implementation.

2. Unknown time of stock replenishment (purchasing of the next supply of commodity).

3. Variation in quantity between the commodities ordered and supplied.

4. Lack of consistency between records concerning the level of stocks indicated by the storage management personnel, and the true level (differences in stocktaking).

"The factors creating uncertainties in the process of management are risk areas in the field of stocks. The first type of risk is connected with varying level of demand on the commodity. The second type of risk is visible, when there are accidental delays between consecutive supplies, that is the time of waiting for the supply. The third risk factor is connected with the risk of quantitative variations, meaning that the commodity has not been delivered in a proper number or term to maintain the fluidity of sales. The last type of risk is connected with organizational errors, for example in the field of accounting, stocktaking, or deficiencies indication." (Sitek 2006, p. 50).

Risk can be strongly connected with the realization of certain assumptions, 
or with maintaining a current state of affairs that does not initiate or desist particular actions (Monkiewicz 2002, p. 733). The effect of a lack of proper risk identification in the case of stock management can be either a shortage or an excessive amount of a commodity. The consequences of a shortage are: lack of possibility to perform production plans, making it impossible to fulfill customer orders (failure to realize the supply), failure to take advantage of the production possibility of devices, threats in the workplace, damage to the image of the enterprise. Examples of the consequences of the surplus of stocks are: increase in costs of the excessively ordered stock, increase of storage costs, increased costs of credit, or damage/ decay of stock.

\section{Identification and assessment of risk}

Risk management is of significant importance in modern organizations and its implementation is a necessity for proper management of the company. The starting point for further considerations concerning the risk level in a particular organization is complex and conscious risk analysis. "Risk analysis can be compared to the creation of a map of potential threats and evaluating damages that can be caused by them. Risk management can therefore be defined as usage of the map and making decisions to prevent the aforementioned threats" (see Chong, Brown 2001, p. 95).

Therefore, the basic aim of risk management, from the economic point of view, is the improvement of financial results, as well as the creation of such conditions that losses do not exceed assumed values. Such actions should lead to the most effective risk limitations and protection against its effects. Such management is mainly connected with evaluation of risk, its measurement and proper control (Kaczmarek 2008, p. 95).

Risk management in the enterprise is connected with, among others, the following activities (Kaczmarek 2008, pp. 95-98):

- specification of responsibilities of the managers for managing particular sections and branches of the enterprise,

- specification of the possible risk occurring in all phases of the decision-making process and undertaking actions aimed at minimizing it,

- indication of the border value concerning risk management as a value specified in a proper proportion to possible operational profit of the enterprise, defining to what extent the risk will be significant or harmful,

- being in possession of an efficient early warning system concerning indicated risk factors, 
- taking unlikely or improbable threats in a given situation into consideration,

- constant control and measurement of risk during realization of tasks of the enterprise,

- increasing the top and medium-level members of the organization awareness that the management risk aims are their management aims as well.

A risk management system is the entire process of the identification, control, and elimination of risk, or its limitation to an acceptable level. In order to increase company performance, risk management should be a systematic process. It is not necessary for the organization to complete all levels of the process, as the most important element is to make all procedures and solutions known and realized automatically (Pritchard 2002, p. 4)

Identification of risk is the first phase of risk analysis. In this field, the following activities are realized (Kaczmarek 2008, p. 98):

- specification of risk causes,

- identification of possible after-effects,

- identification of entities affected by the risk.

The aim of all these undertakings is to become fully aware of real threats in order to make it possible for the company to operate, as well as for them not to interfere with its operation.

In the moment of assessment of risk, the management analyzes numerous events of prominent importance for the organization and its aims concerning the aspects of the risk profile of the particular company - its amount, level of complexity, specifics, etc.

While evaluating risk, both expected and unexpected events should be taken into consideration. Many events are typical and systematic, and they are taken into account by various management programs and current budgets (for example, exploitation of a part of the production equipment), other events are unexpected (such as breakdowns). One of the basic tasks of the management team is to evaluate the risk of potential and unexpected events, as well as prospective occurrences, which can influence the operation of the company.

The uncertainty of potential events is evaluated by measuring two factors: probability and effects. Probability is the possibility that a particular event will take place, and effects are influences of a particular occurrence on the organization. Probability and effects are widely used terms. However, they are sometimes replaced by company specific definitions, such as: possibility of occurrence, consequences, influence.

"According to the principles of decisive analysis, four factors should be taken into consideration while evaluating the level of the risk: (1) amount of losses, (2) possibility of losses occurrence, (3) amount of profit, (4) possibility of profit 
occurrence" (Zaleśkiewicz 2004, p. 90). Using these variables, one can create quantitative criteria (for example, possibility of loss or gain), which will help to evaluate the prominence of the risk. However, surveys show that people tend to evaluate risk based on qualitative, not quantitative criteria (see Slovic, 2001, passim). The quantitative factors are, among others: knowledge, trust, influence, willingness to take risk, immediacy (possibility to delay the loss), level of loss, feeling of anxiety, concentration of media attention, accustomization to the situation. Many of these examples correlate with one another. By combining these dimensions, one can obtain a number of basic risk evaluation factors.

\section{Identification and assessment of risk in company $X$. The case study}

\subsection{Identification of risk}

Analysis of company operations shows that in many companies, formalized, systematic, and ordered identification of risk is not conducted. In many cases this process does take place, however, and is realized intuitively, on a bigger or smaller scale, and on the level of branches or headquarters. Its effectiveness is highly dependent on the experience of employees and their knowledge concerning the principles of the company's operation.

The process of risk identification is most effective if it is formalized. Members of all levels of the organization should be obliged to record risk identification systematically.

Identification of risk is the process of searching for possibilities, and events that can lead to failure to achieve a set task.

The table 2 presents the most important aims of storage and management of stocks, as well as the most important events that can lead to failure to achieve the task.

Table 2. Aims of storage and events influencing it negatively

\begin{tabular}{l|l}
\hline Aim & Event \\
\hline $\begin{array}{l}\text { Keeping the commodities in an unchanged condi- } \\
\text { tion until the moment of sale (or usage by the com- } \\
\text { pany) }\end{array}$ & $\begin{array}{l}\text { A random event (collapse of the building, } \\
\text { flood, etc.), which causes the commodity do } \\
\text { be destroyed. }\end{array}$ \\
$\begin{array}{l}\text { Providing important information about shortages } \\
\text { in advance, leading to maintaining the fluidity of } \\
\text { sales process. }\end{array}$ & $\begin{array}{l}\text { The storage worker controls the amount of the } \\
\text { commodity incorrectly (shortages or the time- } \\
\text { out of the commodity) } \\
\text { Computer system breakdown }\end{array}$ \\
\hline
\end{tabular}

Source: Own research 
The most important aims of stock gathering and transportation and the most important events that may lead to failure to achieve the task are presented in the table 3.

Table 3. The aims of stock gathering and events influencing it negatively

\begin{tabular}{l|l}
\hline Aim & Event \\
\hline Usage in the production process & $\begin{array}{l}\text { Bad quality of delivered commodity } \\
\text { Missed deadline of the supply }\end{array}$ \\
\hline Price competitiveness & Higher price of the commodity \\
\hline
\end{tabular}

Source: Own research

The most important aims of package gathering and transportation and the most important events that may lead to failure to achieve the task are presented in the table 4.

Table 4. The aims of package gathering and events influencing it negatively

\begin{tabular}{l|l}
\hline Aim & Event \\
\hline $\begin{array}{l}\text { Usage in the packing for transportation and sell- } \\
\text { ing of the particular commodity }\end{array}$ & $\begin{array}{l}\text { Bad quality of delivered commodity } \\
\text { Missed deadline of the supply } \\
\text { No possibility to return to the aftermarket }\end{array}$ \\
$\begin{array}{l}\text { Usage for advertisement (creation of the image } \\
\text { of the product) }\end{array}$ & Poor quality of packages \\
\hline
\end{tabular}

Source: Own research

Informal identification of risk in the enterprise is realized mainly by the analysis of documentation. The condition of its effectiveness and performance is the proper quality of data and experience, as well as the required skills of the person preparing the analysis. The analyzed reports include current stock status (stocks available in a given period).

\subsection{Risk assessment}

Analysis of the enterprises' operations indicated that the evaluation of the risk was not performed in a formalized, systematic, or ordered manner. It should be also assumed that the procedure is executed intuitively on a larger or smaller scale in the field of branches or headquarters. Its effectiveness depends on the 
experience of employees and their knowledge concerning the scheme of the company's operation.

The process of the evaluation should be formalized and employees on every level of the company's hierarchy should be obliged to perform it. One of the most useful methods to evaluate formalized risk is the risk matrix.

"In the case of the risk matrix, just as in other measurements of risk, both dimensions are taken into consideration: the amount of possible losses and the probability of loss occurrence" (Zellmer, Wasilewski 2010, p. 403). No numerical value will be specified for each of the variables, but in both cases, an ordinal scale of evaluation will be identified, including small, medium, and high levels. For each identified risk, one should perform such evaluation and chose a proper value for the amount of losses and probability of loss. The general form of the matrix is presented in the following illustration:

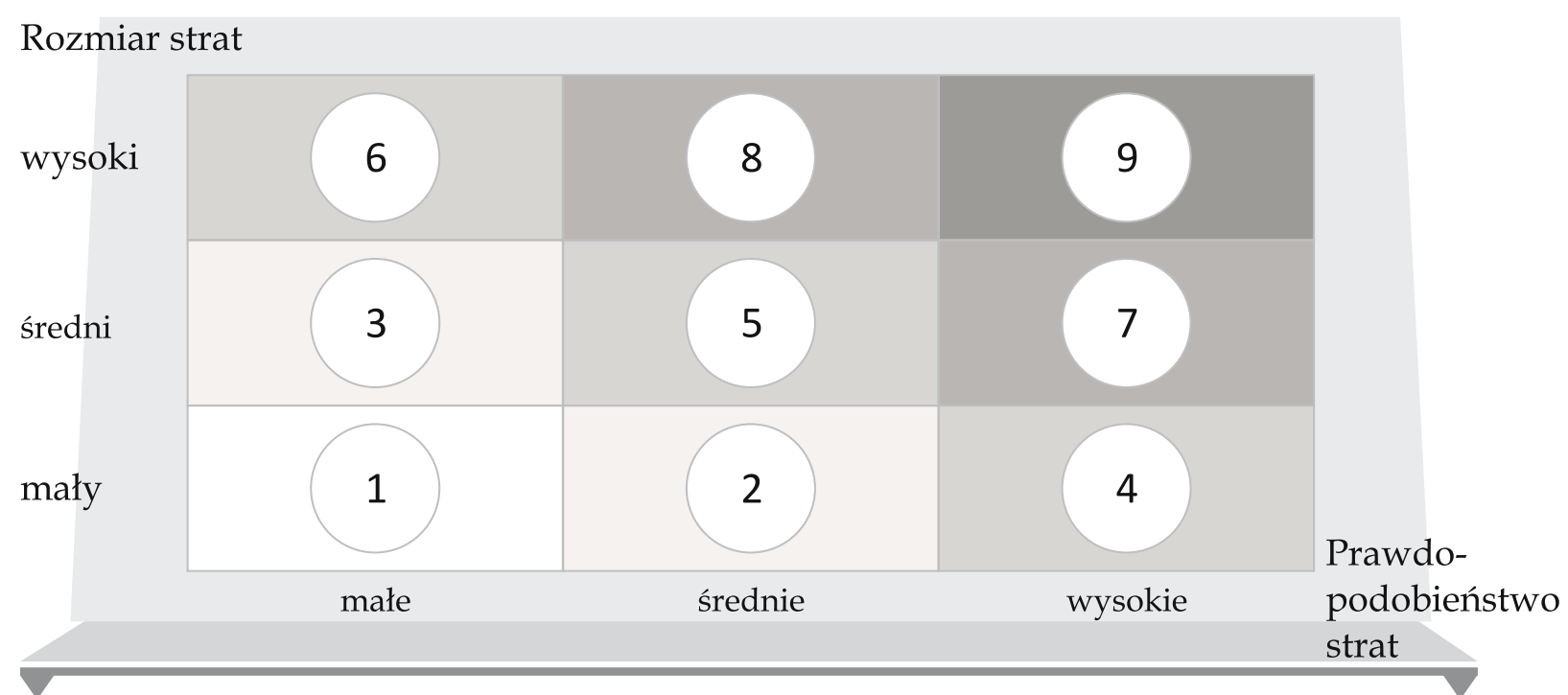

Figure 1. The general form of the risk matrix

Source: Zellmer G., Wasilewski W. 2010, p. 404

On the basis of nine fields of the matrix, one can evaluate the level of the risk, providing that the scale of values presented below is used:

very low risk (field 1 ),

low risk (fields 2 and 3 ),

medium risk (fields 4,5 and 6 ),

high risk (fields 7 and 8 ),

very high risk (field 9). 
An example of formalized risk evaluation in the storage of ready-made products is presented below.

Table 5. Storage risk evaluation

\begin{tabular}{l|l|c|c}
\hline No. & Event & Probability & Amount \\
\hline $\mathbf{1}$ & $\begin{array}{l}\text { A random event (collapse of the building, flood, etc.), which } \\
\text { causes the commodity do be destroyed. }\end{array}$ & Small & High \\
\hline $\mathbf{2}$ & $\begin{array}{l}\text { The storage worker controls the amount of the commodity in- } \\
\text { correctly (shortages or the timeout of the commodity) }\end{array}$ & High & Medium \\
\hline $\mathbf{3}$ & Breakdown of the computer system & Medium & Medium \\
\hline
\end{tabular}

Source: Own research

Table 6. Matrix of storage risk

Amount of losses

High

Medium

Low

\begin{tabular}{|l|l|l|}
\hline 1 & & \\
\hline & 3 & 2 \\
\hline & & \\
\hline
\end{tabular}

Low

Medium

High

Probability of loss

Source: Own research

On this basis, we can assume that:

Event 1 - medium risk

Event 2 - high risk

Event 3 - medium risk

The result of the analysis should make it possible to specify certain priorities in coping with the risk. We can evaluate which risk should be taken care of first, because it may influence the possibility of further operation of the company. We may also evaluate risks which it is not necessary to take care of, because they are not considered a threat to the enterprise, and would be connected with unnecessary expenditure.

While analyzing stock risk, it should be noted that the risk connected with event number 2 should be the subject of an immediate reaction by the company. Events number 1 and 3 should be taken care of subsequently.

A formalized evaluation of risk of acquisition of semi-products and their transportation is presented below. 
Table 7. Evaluation of risk of acquisition of semi-products and their transportation

\begin{tabular}{l|l|c|c}
\hline No & Event & Probability & Amount \\
\hline $\mathbf{1}$ & Bad quality of delivered commodity & Medium & High \\
\hline $\mathbf{2}$ & Missed deadline & High & High \\
\hline $\mathbf{3}$ & Higher price of the delivered commodity & Medium & Medium \\
\hline
\end{tabular}

Source: Own research

Table 8. Matrix of acquisition of semi-products and their transportation The amount of losses

High
Medium
Low

\begin{tabular}{|l|l|l|}
\hline & 1 & 2 \\
\hline & 3 & \\
\hline & & \\
\hline
\end{tabular}

High Medium Low $\quad$ Lobality

Source: own research

On this basis, we can assume that:

Event 1 - high risk, Event 2 - very high risk, Event 3 - medium risk

In the case of the risk connected with acquisition of semi-products, it should be noted that the risk connected with the event number 2 should be the subject of immediate an reaction by the company. Event number 1 should be dealt with next, and event number 3 should be dealt with after this.

An example of the formalized evaluation of the risk of acquisition of packages used for storage and transporting purposes is presented below.

Table 9. Evaluation of the risk of acquisition of packages used for storage and transporting purposes

\begin{tabular}{l|l|c|c}
\hline No & Event & Probability & Amount \\
\hline $\mathbf{1}$ & Bad quality of supplied commodity & Low & High \\
\hline $\mathbf{2}$ & Missed deadlines & Low & High \\
\hline $\mathbf{3}$ & No possibility to return to the aftermarket & High & Medium \\
\hline $\mathbf{4}$ & Poor package quality & Low & Low \\
\hline
\end{tabular}

Source: Own research 
Table 10. The matrix of the risk of acquisition of packages used for storage and transporting purposes

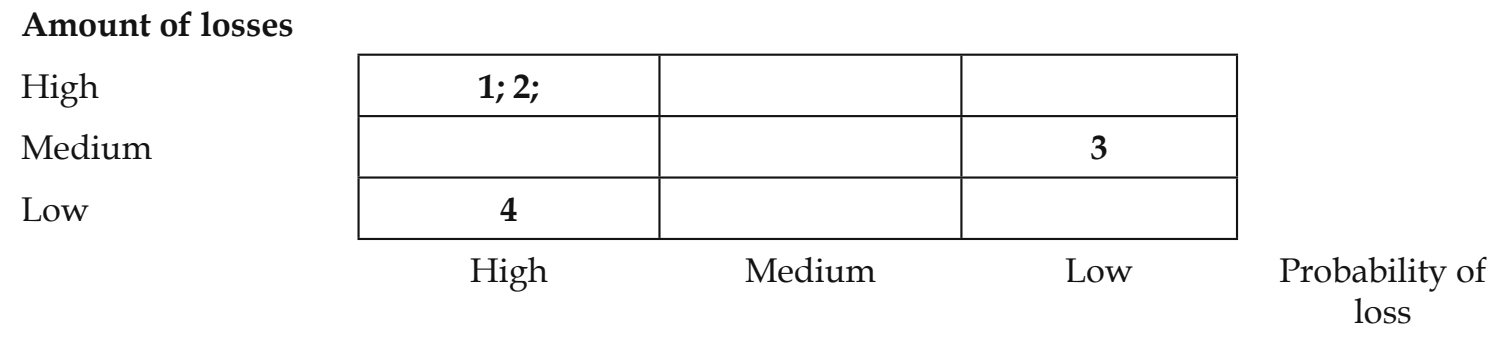

Source: own research

On this basis, we can assume that:

Event 1 - medium risk, Event 2 - medium risk, Event 3 - high risk, Event 4 small risk

In the case of the risk connected with the acquisition of packages, it should be noted that event number 3 should be the subject of immediate reaction by the company. Events number 1 and 2 should be dealt with later. It is possible to omit event number 4 and its risk.

\section{Conclusions}

Every organization must face risk during its operation. Quick identification and effective evaluation of its level makes it possible to maintain fluidity of activities on the market at a constant level. In the majority of cases, such processes are not formalized and they take place intuitively. Implementation of a formalized process of risk analysis is beneficial for companies, especially in the field of business decision making.

Even though the characteristic of the risk and shortages of data can cause serious problems during formalization and implementation of the risk analysis system in the company, the benefits can exceed the costs.

\section{Summary}

The supply risk analysis process in small and medium enterprises

The identification and evaluation of risk, especially in small and medium enterprises - has been a topic of examination by scientists from the very beginning. Expenditure connected with the implementation and proper execution of risk measurement 
methods is also of prominent importance.

Every organization must face risk during its operation. Quick identification and effective evaluation of its level makes it possible to maintain fluidity of activities on the market at a constant level. In the majority of cases, such processes are not formalized and they take place intuitively. Implementation of a formalized process of risk analysis is beneficial for companies, especially in the field of business decision making.

The aim of this paper is to present the process of risk analysis in an exemple company and to present possibilities for its implementation in small and medium enterprises.

Keywords: risk, risk analysis, risk identification, risk assessment

\section{Streszczenie}

Słowa

Proces analizy ryzyka zaopatrzenia $w$ małych i średnich przedsiębiorstwach

Identyfikacja i ocena ryzyka - zwłaszcza w małych i średnich przedsiębiorstwach - należały od początku do tematów badawczych naukowców. Znaczące są również nakłady związane $\mathrm{z}$ wdrożeniem i poprawnym zastosowaniem ilościowych miar oceny ryzyka.

Każda organizacja musi stawić czoła ryzyku w swojej działalności. Szybka identyfikacja i sprawne oszacowanie jego wielkości pozwala na utrzymanie wysokiej aktywności na rynku. $\mathrm{W}$ większości przypadków procesy te nie są sformalizowane i zachodzą intuicyjnie. Wdrożenie sformalizowanego procesu analizy ryzyka przynosi organizacjom korzyści związane przede wszystkim w zakresie podejmowania decyzji biznesowych

Celem tego artykułu jest przedstawienie procesu analizy ryzyka na przykładowym przedsiębiorstwie oraz zaprezentowanie możliwości jego zastosowania $w$ małych $i$ średnich przedsiębiorstwach.

kluczowe: ryzyko, analiza ryzyka, identyfikacja ryzyka, ocena ryzyka;

\section{References}

1. Chong, Y./ Brown, E. (2001), Zarzadzanie ryzykiem projektu, OE: Dom Wydawniczy ABC, Kraków.

2. Kaczmarek T.T. (2008), Ryzyko i zarzadzanie ryzykiem: ujęcie interdyscyplinarne, Difin, Warszawa. 
3. Monkiewicz J. (2002), Rynek i ryzyko, PWE, Warszawa.

4. Pritchard, C.L. (2002), Zarzadzanie ryzykiem w projektach, WIG-press, Warszawa.

5. Sitek E., red. (2006), Zarzadzanie ryzykiem w działalności gospodarczej, Częstochowa.

6. Slovic P. (2001), Perception of Risk, Londyn.

7. Tempelmeier H. (2000), Produktion und Logistik, Springer-Verlag, Berlin.

8. Zaleśkiewicz T. (2004), Percepcja działań ekonomicznych, w: T. Tyszka (red.), Psychologia ekonomiczna, Gdańskie Wydawnictwo Psychologiczne, Gdańsk.

9. Zellmer, G. Wasilewski, W. (2010), Ocena ryzyka przedsiębiorstwa-podstawy teoretyczne i praktyczne metody, [w:] Problemy zarządzania strategicznego wobec przemian w otoczeniu współczesnych przedsiębiorstw, Uniwersytet Zielonogórski, Zielona Góra.

10. Zellmer G. (1990), Risikomanagement, Die Wirtschaft, Berlin.

11. Zellmer G. (2010), Skrypt do przedmiotu ,Planowanie bezpieczeństwa, Uniwersytet Zielonogórski. 